\title{
A Tiny Comment to Utilizing Religious Sources to Create Environment Friendly Citizens
}

\author{
Yunus Yildiz ${ }^{1}$ \\ ${ }^{1}$ Department of Languages, Faculty of Education, Tishk International University, Erbil, Iraq \\ Correspondence: Yunus Yildiz, Department of Languages, Faculty of Education, Tishk International University, \\ Erbil, 44001, Iraq. Tel: 964-750-306-5416. E-mail: yunus.yildiz@ishik.edu.iq
}

Received: April 24, 2019

doi:10.5539/ass.v15n6p101
Accepted: May 4, 2019 Online Published: May 31, 2019

URL: https://doi.org/10.5539/ass.v15n6p101

\begin{abstract}
The world's assets are lessening and nature is in retreat. In less than a century, human populace and its needs for space, materials, merchandise, and conveniences have enlarged more than four times. Some of the environment spoiling problems are to remember: the over-cut of woods, depleting of wetlands, spread of horticultural advancement and high rates of pesticide and compost use, the spread of wild nuisances, unplanned clearing of forest for household stock, urbanization of foreshores, and the contamination of streams and estuaries. All these natural harms are caused because of thoughtless human works. Knowing these, issues about environmental cleaning, protecting the environment, to prevent damage to the ecological balance and such issues have been being mentioned and emphasized too often in media outlets in the last two decades. In order to implement these highlighted issues in society, foundations and associations are formed. These organizations foster to set up various activities to intensify people's attention to the subject and create environmental awareness among public.

Herewith, so many dynamics can be utilized to motivate people to be well and responsible in life. Among the dynamics, one of the most important factors that motivates people at ease is religion. Benefiting from religious motivation or sources while changing people's habits or perceptions can be a good solution in shaping conscious citizens. Moreover, to make people more sensitive about these issues and more addicted to their responsibilities, religions' effect is inevitable. In this article, the researcher points out that with the aid of diversity and complexity of religious sources, better environment friendly citizens may appear in the society.
\end{abstract}

Keywords: religious sources, environmental awareness, various activities, religion, motivation, contamination

\section{Introduction}

"Beings in the universe constitute an interrelated hierarchical order. The smallest and least complicated piece is in interaction with larger and more complex systems and work together. Each level is a whole dynamic within the unit itself, but the unit cannot be considered present without the link above or below" (Tosun, 1992). Naturally, human is a part of this system, but he reaches a different structure and consciousness level by his psychological presence and establishes social formation with other assets. As a result, he gains a conscious relevance with other entities.

In reality, we are born as a guest in the earth, get into a relationship with our natural environment, and our social life perception produces a consciousness in our personal life. In bible, Genesis 2:7, it says, 'Then the LORD God formed man from the dust of the ground, and breathed into his nostrils the breath of life; And the man became a living being' (Coogan, 2018). We get closer to our natural environment in thought and behavior having received from our childhood that is inherited from our family and social environment. Thus, we see that our social environment doesn't see or ignore many things. We claim that we have to do a lot of things to protect our environment. However, we are not even close to be aware of them. Because we haven't established the environment and being in the same form of life regularly blinded our eyes. Every moment we breathe air, light and temperature that we rely on the sun, the air that produces oxygen for us and psychological gratification that trees supply and the blue sky that cleans our brain are routine and usual events for human beings. In fact, all these happenings attract people, but we really do not comprehend their value and existence as it has to be expected.

Qur'an emphasizes in many verses of surahs (observe in Qur'an 14/32, 16/12, 14, 22/65, 29/61, 31/20, 35/13, 
$39 / 5,45 / 13)$ that this course layout has been created by Allah Almighty has blessed us. 'To God belongs what is in the heavens and what is on earth, and God encompasses everything' (Itani, 2012). It's obvious the value given to man by God is an indication. The Holy Quran states that on earth and in the sky all animate and inanimate beings live in a certain measure and balance created. According to surah-i Rahman 'and the Firmament has He raised high, and He has set up the Balance of Justice, 55/7-12'. Humankind should deal with nature a measured and balanced relationship to benefit from it the longest possible period of time. From the beginning of mankind until the Day of Judgment, humankind will act in nature, will benefit from it to produce things that are necessary to survive. However, naturally, some of the items are suitable for immediate use while many substances found in crude form. People who are in need of many things to produce have to remember that producing causes consuming, and in order to consume we need to produce and it needs balance.

While consuming nature of which, that there are a very important consideration to the order of nature we call the ecological balance (ecosystem), we should pay attention not to spoil it. However, most of the time mankind is heedless. Actions that people take cause the fatal damage to the natural environment and operate unimaginable destructions. This should be well known that humankind is actually cutting his own throat by environmental damages. Irresponsible destruction of nature and pollution of the environment dismissively is a complete spendthrift attitude. How spendthrift and empty handed are who squander their winnings after a while, and remain in a miserable condition, like that environmental pollutants who thoughtlessly destroy the world for their own doings will find themselves in an uninhabitable world. Quran hit some calamity to the people that their doings as a result 'Whatever misfortune befalls you, it is because of what your hands have earned; and yet $\mathrm{He}$ pardons much. Shuara 42/30.', in addition the verse 'Corruption has appeared on land and sea, because of what people's hands have earned, in order to make them taste some of what they have done, so that they might return. Rum 30/41' emphasizes a criminal action humankind presents.

Appearently, air pollution, the world's being lack of green, the ozone layer's being thinner and water sources being dirty are the major problems. However, these results are not a surprise to people. It is a natural consequence of people's own doings. Indeed, these days humanity has been facing dizzying developments in industry and technology fields since 19th century. Famous Russian philosopher Tolstoy said that "The material progress achieved in the nineteenth century is truly enormous, but it was, and still is being, purchased at a cost of neglect for the most elementary demands of morality, such as humanity has never witnessed before, not even under Genghis Khan, Attila, or Nero. On Truth \& Reality (2019).

Because of industrial wastes our land is infertile, rivers, our lakes, and our seas are getting lack of fish, cities are built destroying forests in the name of civilization, but no precautions are taken against this destruction. As it is said by an anonymous Indian chief; 'We do not inherit this earth from our ancestors; we borrow it from our children. We are harmful to the nature and our world with our irresponsible attitude. Moreover, we are about to leave our children an uninhabitable world'.

Environmental awareness education should also be fed by religion, philosophy, tradition and ideology (Aygün \& Herdem, 2014).

Therefore, environment education has a paramount role on shaping sensitive society and environment education is defined as individuals' active participation in the solution of natural, historical, cultural, socio-ethical values and environmental problems (Alım, 2006).

\section{Environmental Issues in Different Religious Sources}

Yildirim (2012) claims that there are about five hundred verses in holy Qur'an that guide us in environmental issues and teach us how to treat the environment.

Religions with a light in front of humanity, are considered not only about belief and worship, but also some of the tasks people have to set in their lives. Their orders about every aspect of human life, is to give recommendations and warnings. Therefore, believers relying on this issue keep number of orders, advice and warnings. They may be mentioned in religions in the ways, as follows:

1. Religion Islam teaches Muslim believers to respect all beings, and to consider their lives sacred 'And do not kill the soul which God has made sacred, except in the course of justice' Isra 17/33. Because all Muslims, "Praising Him are the seven heavens, and the earth, and everyone in them. There is not a thing that does not glorify Him with praise, but you do not understand their praises. He is indeed Forbearing and Forgiving" (Isra, 17/44) carry the faith. Hence, we could say that Muslims cannot destroy the environment irresponsibly or unconsciously.

Christianity approaches the same issue as 'The designer and maker of the earth established the earth, not creating 
it to be a waste, but designing it to be lived in. Isaiah 45:18' (Ludwig, 1973).

This point is, in terms of environmental awareness, an important issue to take account. The one who gathers this awareness will be restrained with the environment of the area accordingly. At least, he will see around friendly and helpful. Believers will be careful not to disturb the balance while benefiting from them.

2. Qur'an counts waste forbidden, and extravagance is brotherhood of Satan's 'O Children of Adam! Dress properly at every place of worship, and eat and drink, but do not be excessive. He does not love the excessive A'raf 7/31' and the Prophet Muhammad even while taking ablution for prayer from a stream also warns the believers that water must be used economically (Akyüz, 2015), 'and gave orders and advice on not to spill garbage in the immediate vicinity of drinking water' (Armağan, 1992, p. 250). Thus, these words will be an important foundation in creating environmental consciousness for society.

Besides, in Judaism, The Halakhah (Jewish law) bans wasteful consumption. Wasting resources mean to violate the mitzvah (commandment) of Bal Tashchit (Do not destroy). It is mentioned on Contemporary English Version of Deuteronomy 20:19-20 that; 'When you are attacking a town, don't chop down its fruit trees, not even if you have had the town surrounded for a long time. Fruit trees aren't your enemies, and they produce food that you can eat, so don't cut them down. You may need wood to make ladders and towers to help you get over the walls and capture the town. But use only trees that you know are not fruit trees' (Lerner \& Rabello, 2006, p. 174). Somehow, religions are stating the same issues in different words.

3. A Muslim believer knows that the names of Allah are represented in man. Quddus is a name of one of Allah's names. Quddus means holy or clean. This is the name of Our Lord on earth as a manifestation and as continuous contamination occurs in the world, Allah cleans the environment by the established ecological system. Thousands of dead animal carcasses, dried plant residues (by a chemical change) are cleaned each season. Also, winds sweeps through the earth and literally washes away with the rain. At this point, a Muslim believer as having the reflection of the name Quddus have to clean the environment and fill up all duties that are expected.

4. Considering the context of the environment, believers have to be conscious and prevent environmental pollution and to do is they must be covered with the God's morality. In addition, there is a Midrash (Rabbinic commentary on the Bible) which Jewish environmentalists are keen on quoting (Troster, 2004): "When God created the first human beings, God led them around the Garden of Eden and said: "Look at my works! See how beautiful they are-how excellent! For your sake I created them all. See to it that you do not spoil and destroy my world; For if you do, there will be no one else to repair it. Midrash Kohelet Rabbah, 1 on Ecclesiastes 7:13" p.5.

5. Qur'an declares that the task of reconstruction the earth is the duty of people. In one verse of Quran ordered, 'And to Thamood, their brother Saleh. He said, "O my people, worship God, you have no god other than Him. He initiated you from the earth, and settled you in it. So seek His forgiveness, and repent to Him. My Lord is Near and Responsive (Surah Hud, 11/61)'.

In the verse a word has two meanings by the exegetes. The first of these in which Ibn Kathir's Tafsir is pointed that "God, made you, the earth builders (Recite Qur'an, 2019, p. 228)". Secondly, in İbn'l-Cevzi's Zadü'l-Mesir, it is commented that "God wanted you to decorate the earth is in the form" (Mert, 2008). Islamic scholars, based on the performance of abode, indicate that, people should open water channels, and develop reforestation efforts in the community. These deeds are assumed as the signal of being a Muslim believer. Human beings will develop the world as a religious duty because Muslim morality requires it, but Muslim should do this without destroying nature.

6. Prophet Muhammad orders people to keep the city clean and gives people some advice to pay attention on the protection of plants and animals. At this point, the Prophet commands that mosques should be built among the houses (in each neighborhood), and that they should be cleaned and perfumed. In Islamqa.com, (1996) is demonstrated that stagnant pools are not to be urinated, and the waste is not to spill close around of drinking water (Akyüz, 2014).

7. Jewish holy messages accentuate that mankind has a commitment to improve the world for future generations, Jewish custom urges families and networks to decrease their waste and settle on shrewd buyer decisions, putting resources into organizations that don't contaminate and supporting practices and strategies that empower protection.

8. According to Hadith (Prophet Muhammad's sayings, deeds and teachings) that demonstrates, the Holy Prophet, like in all matters is a great example for his followers about environment protection and keeping it clean too. Muhammad encourages believers for tree planting (Özdemir, 2002) as well, indicating that; "If you have a sapling, if you have the time, be certain to plant it, even if Doomsday starts to break forth." In another hadith, 
Islam (2004) reminds us that 'If a Muslim plants a tree, that part of its produce consumed by men will be as almsgiving for him. Any fruit stolen from the tree will also be as almsgiving for him. That which the birds eat will also be as almsgiving for him. Any of its produce which people may eat thus diminishing it, will be as almsgiving for the Muslims who planted it'. The hadiths we have already read are a full indicator to create the incentive and sensitive environmental awareness among believers.

9. The leaders of the Sahaba-i Kiram (the Prophet Muhammad's companions) also had this consciousness. For example, İbnü'l-Esir, (2014) in his 'El-Kâmil fi't-Tarih 2/305' says that Abu Bakr, Prophet Muhammad's best companion, while addressing Usama's army said; "Do not disassemble or incinerate palm trees, don't cull other fruit trees, and don't eat the sheep, cattle and other animals for any purposes other than cut in case of hunger", and Uthman, as being the third caliph of Ummah, while planting trees in a late time, a person comes and asks "O Emir of the Faithful! Are you doing planting at this time?" and his response 'The time you came to me, caught me doing such a charitable work, is much better and cuter than found me free and idle one like those who were destroyer (Hadislerle Islam, 2019, p. 377)'. Even this reply implies how much the environmental awareness was settled as a form of life among companions.

10. Historically speaking, this issue has been a source of inspiration in the spirit of ancestors. They built the cities where they lived the most prosperous, pursued the effort of making livable spaces. Here, Conqueror of Istanbul, Fatih Sultan Mehmet, after the conquest of Tashlik locality, bought 136 shops to start an active trade and to consecrate the area, he set some rules meant that, "Every street will have two people to do cleaning in Istanbul. They are responsible for holding a bowl of lime powder and coal ash in hands at certain times of day in these streets. These streets which have spitting of saliva must be cleaned by spreading powder dumps. And those people are given 20 akcha weekly. In addition, 10 surgeons, 10 physicians and 3 wound wrappers are responsible to find out by knocking at the doors if there are any people suffering from illnesses on certain days in Istanbul to treat and give healing if possible" (Özdemir \& Yükselmiş, 1995, pp. 126-127).

\section{Conclusion and Recommendations}

Simkins, (2008) argues that "The notion that religions might be influential enough to help shift whole societies in more environmentally benign and sustainable directions might seem fanciful. But, religions can bring considerable resources to such an effort". Besides this reality, it is pointed in Evangelical Declaration on the Care of Creation, (1994) that 'Because we worship and honor the Creator, we seek to cherish and care for the creation. Because we have sinned, we have failed in our stewardship of creation. Therefore we repent of the way we have polluted, distorted, or destroyed so much of the Creator's work'. Herewith, to love nature, to protect the environment, and to keep it clean is a religious order for humanity. This is why, devout people should be environmentalist and spread this awareness from generation to generation. For this, actions to be taken might be as follows:

a. Religious aspects of environmental issues must be as often as possible brought up in press and media.

b. Community pioneers should coordinate individuals about environmentalism, even they ought to compose exercises actually about environmentalism.

c. Tending to natural equity issues in the places of worship can be testing. All alone, issues of race, poverty or pollution can be intense going. Together, they drive us to rethink our comprehension about the structures of our public, and to look cautiously - and horrendously - at who advantages and who is hurt by those structures. Therefore, Department of Religious Affairs of any countries should direct the preachers or priests to give sermons on these issues and holy week periods should be used effectively.

d. In addition, conferences, scientific events such as panel discussions and symposia should be organized by governmental and non-governmental organizations with religious sensitivities and activists.

e. The last but not least, the people who are raising people to clean environment must be first well aware about environment awareness and live their words while telling against people.

Religions' stand on environment is very clear. To get back the wonderful condition and unhazardous nature, religious instructions and rules are very motivational. Religious eco-ethics should be actualized at all dimensions - neighborhood, national, territorial, worldwide and in particular, at individual dimension.

\section{References}

Akyüz, H. (2014). Çevre Dostu Bir Peygamber: Hz. Muhammed. Electronic Turkish Studies, 9(2). https://doi.org/10.7827/TurkishStudies.6318

Akyüz, H. (2015). Ot, Su ve Ateşin Ortak Kullanımı İle İlgili Bir Hadisin Güncel ve Evrensel Değeri. Itobiad: 
Journal of the Human \& Social Science Researches, 4(1). https://doi.org/10.15869/itobiad.93907

Alım, M. (2006). Avrupa Birliği Üyelik Sürecinde Türkiye'de Çevre ve İlkoğretimde Çevre Eğitimi. Kastamonu Eğitim Dergisi, 14(2), 599-616.

Armağan S. (1992). İslam Çevre Hukukunun Genel Esasları. İslam ve Çevre. Istanbul: Gündönümü Yay.

Aygün, H. A., \& Herdem, K. (2014). Ayet ve Hadislerle Desteklenmiş Materyallerin Çevre Eğitimine Katkısı. Milli Ë̆itim Dergisi, 45(209), 256-269.

Coogan, M. (2018). The New Oxford Annotated Bible: New Revised Standard Version. Oxford University Press.

Evangelical Declaration on the Care of Creation. (1994). Retrieved March 22, 2019, from https://www.creationcare.org/evangelical_declaration_on_the_care_of_creation

Hadislerle Islam. (2019). Çevre / Tabiat Bizim Kardeşimiz. Retrieved March 24, 2019, from https://hadislerleislam.diyanet.gov.tr/?p=kitap\&i=7.0.377

İbnü'l-Esir. (2014). El-Kâmil fi't-Tarih Tercumesi. Bahar Yaytnlart. Retrieved March 22, 2019, from https://archive.org/details/IbnulEsirElKamilFitTarih2/page/n305

Islam, M. M. (2004). Towards a green earth: An Islamic perspective. Asian Affairs, 26(4), 44-89.

Islamqa.com. (1996). Cleaning the mosque. Al-Tirmidhi, 594; Al-Targheeb wa'l-Tarheeb, 279. Retrieved March 24, 2019, from https://islamqa.info/en/answers/20160/cleaning-the-mosque

Itani, T. (2012). This Quran could not have been produced by anyone other than God: The Quran. Published by ClearQuran, Dallas and Beirut.

Lerner, P., \& Rabello, A. M. (2006). The Prohibition of Ritual Slaughtering (Kosher Shechita and Halal) and Freedom of Religion of Minorities. Journal of Law and Religion, 22(1), 1-62. https://doi.org/10.1017/S0748081400003210

Ludwig, T. M. (1973). The traditions of the establishing of the earth in Deutero-Isaiah. Journal of Biblical Literature, 92(3), 345-357. https://doi.org/10.2307/3263576

Mert, M. (2008). Çevre Bilinci Oluşturmada İslam'ın Katkısı Üzerine. Çevre ve Din. Uluslararası Çevre ve Din Sempozyumu Bildiri Metinleri, 26-30.

On Truth \& Reality. (2019). The Wave Structure of Matter (WSM) in Space Theology. Religion. God. Retrieved March 24, 2019, from https://www.spaceandmotion.com/Religions-Leo-Tolstoy-True-Religion.htm

Özdemir, İ. (2002). An Islamic approach to the environment. Retrieved March 24, 2019, from http://www. environment-ecology.com/religion-and-ecology/489-an-islamic-approach-to-the-environment.pdf

Özdemir, İ., \& Yükselmiş, M. (1995). Environmental Problems and Islam. Çevre Sorunları ve İslam. Ankara: DIB Yay.

Recite Qur'an. (2019). Retrieved March 24, 2019, from http://www.recitequran.com/tafsir/en.Ibn Kathir /11:61

Simkins, R. A. (2008). Religion and the Environment. Journal of Religion and Society, 10, 159-183.

Tosun, M. (1992). Psikolojik Açıdan Çevre ve İnsan. İnsan ve Çevre. İstanbul: İnsanlı̆̆a Saygı Vakfı Yay., 56-57.

Troster, L. (2004). Repairing the order of creation: A Jewish perspective on environmental ethics. Environmental Practice, 6(1), 2-6. https://doi.org/10.1017/S146604660400002X

Yildirim, Z. (2012). Kur'an Ve Çevre Sorunlari. Atatürk Üniversitesi Illahiyat Fakültesi Dergisi, (38), 67-100.

\section{Copyrights}

Copyright for this article is retained by the author(s), with first publication rights granted to the journal.

This is an open-access article distributed under the terms and conditions of the Creative Commons Attribution license (http://creativecommons.org/licenses/by/4.0/). 